Jurnal Tanah dan Sumberdaya Lahan Vol 8 No 2: 493-504, 2021

e-ISSN:2549-9793, doi: 10.21776/ub.jts1.2021.008.2.20

\title{
ANALISIS PERMEABILITAS TANAH LAPISAN ATAS DAN BAWAH DI LAHAN KOPI ROBUSTA
}

\section{Permeability Analysis of Topsoil and Subsoil at Robusta Coffee Land}

\author{
Febri Ayu Alista*, Soemarno \\ Jurusan Tanah, Fakultas Pertanian, Universitas Brawijaya, Jl. Veteran No. 1 Malang 65145 \\ *Penulis korespondensi: febriayualista@gmail.com
}

\begin{abstract}
Coffee (Coffea sp.) is one of the leading commodities in Indonesia for it has a high economic value. In Bangelan Village, Malang Regency, there is a company that manages robusta coffee commodity. The land was converted into a coffee plantation from forest land. The conversion of forest land into a coffee plantation caused the decreasing number of total soil pores lower than the forest land. This will make it difficult for water to absorb into the soil. This study was conducted in Afdeling Besaran, PT. Perkebunan Nusantara XII Kebun Bangelan to elucidate the value of soil permeability and the nature of the relationship between them. The result of this study indicated that the permeability of the soil on each land map unit was in the category of fast permeability class and slightly fast permeability class. The highest soil permeability value was found on land map unit 2 at the 56 years average age of coffee robusta field, with each depth of $6.03 \mathrm{~cm}^{\text {hour }}{ }^{-1}, 7.95 \mathrm{~cm} \mathrm{hour}^{-1}$, and $7.82 \mathrm{~cm}$ hour ${ }^{-1}$. Soil permeability is influenced by soil porosity, sand and silt with a positive correlation way. In addition, aggregate stability, soil bulk density and clay also significantly affected the soil permeability with a negative correlation way. Permeability affected the production of robusta coffee plants with a positive correlation way of $16.09 \%$.
\end{abstract}

Keywords : coffee field age, robusta coffee, soil permeability, soil physical properties

\section{Pendahuluan}

Komoditas perkebunan memegang peranan penting dalam program pembangunan pertanian karena memiliki nilai ekonomis yang tinggi. Indonesia menduduki posisi ketiga sebagai negara ekspor kopi setelah Brazil dan Vietnam. Kopi (Coffea sp.) merupakan salah satu komoditas perkebunan Indonesia dengan volume produksi terbesar keenam setelah kelapa sawit, karet, kelapa, tebu dan kakao (Wulandari, 2010). Pada tahun 2000 hingga 2010 persentase ekspor kopi meningkat dari 4,7\% menjadi 14,7\% (Baroh et al., 2014). Salah satu penghasil kopi terbesar di Indonesia adalah Jawa Timur. Menurut Dinas Perkebunan Provinsi Jawa Timur (2017) menyatakan bahwa wilayah Kabupaten Malang merupakan penghasil kopi terbesar di Jawa Timur. Jenis kopi yang memiliki produksi tinggi adalah kopi robusta. Produksi kopi robusta di Malang sebesar 10284 ton sedangkan kopi arabika sebesar 488 ton (BPS, 2019).

Desa Bangelan merupakan desa yang terletak di Kabupaten Malang, dimana terdapat tanaman kopi robusta yang dikelola oleh perusahaan yaitu PTPN XII Kebun Bangelan. Lahan kebun kopi tersebut awalnya merupakan lahan hutan yang dikonversi menjadi kebun kopi dan dikelola sebagai kebun kopi produktif selama bertahun-tahun hingga saat ini. Kegiatan alih fungsi lahan memungkinkan terjadinya degradasi lahan. Degradasi lahan adalah proses penurunan produktivitas lahan yang sifatnya sementara maupun tetap, dicirikan dengan penurunan sifat fisik, kimia dan biologi (Wahyunto dan Ai, 2014). Penurunan sifat fisik tanah akibat alih fungsi lahan ditunjukkan dengan adanya pemadatan tanah, sehingga dapat menyebabkan porositas tanah menurun. Menurut Widianto et al. (2004), Hairiah et al. (2004), Simanjuntak (2005), dan Suprayogo et al. 


\section{Jurnal Tanah dan Sumberdaya Lahan Vol 8 No 2: 493-504, 2021 \\ e-ISSN:2549-9793, doi: 10.21776/ub.jts1.2021.008.2.20}

(2016), alih fungsi lahan hutan menjadi kebun kopi dan pengelolaan kebun kopi secara rutin telah menyebabkan penurunan total-pori dan pori makro tanah.

Pada tahun 2014 telah dilakukan penelitian di kebun kopi Desa Bangelan oleh Widianto et al. (2017) yang menganalisis perubahan porositas tanah akibat pemberian beberapa jenis bahan organik di kebun kopi robusta. Namun hingga saat ini belum ada penelitian lebih lanjut mengenai hasil dari perlakuan peneliti terdahulu terhadap salah satu sifat fisik tanah yaitu permeabilitas tanah di PTPN XII Kebun Bangelan. Permeabilitas tanah mencerminkan kemampuan tanah untuk meloloskan air melalui ruang pori (Siregar, 2013). Permeabilitas tanah ini menentukan seberapa besar air hujan dapat meresap masuk ke dalam tanah dan seberapa besar air hujan menjadi limpasan permukaan. Oleh karena itu diperlukan suatu analisis permeabilitas tanah di lahan kopi robusta khususnya pada lapisan atas dan bawah sebagai langkah awal dalam menyusun strategi memperbaiki kualitas tanah.

\section{Bahan dan Metode}

Penelitian ini dilaksanakan pada bulan November 2019 di Afdeling Besaran, PTPN XII Kebun Bangelan untuk pengambilan sampel. Analisis tanah dilaksanakan di Laboratorium Fisika Tanah, Fakultas Pertanian, Universitas Brawijaya, Malang. Metode penelitian ini dilakukan dengan metode survei yang terdiri dari tahap pra survei, survei dan pasca survei. Penelitian diawali dengan pembuatan peta kerja dn survei pendahuluan. Kemudian penentuan titik pengambilan sampel dengan menggunakan metode purposive random sampling berdasarkan kelas umur kebun kopi yang didalamnya terdiri dari data umur tanaman kopi, data inventaris tanaman penaung, dan data inventaris gulma. Metode klasifikasi kelas umur kebun kopi ini menggunakan rumus Sturges dan Kingma dengan melakukan pengelompokan umur kebun kopi ke dalam kelompok berbentuk kelas interval.

\section{Penentuan jumlah kelas}

Penentuan jumlah kelas menggunakan rumus Sturges (Sturges, 1926). Jumlah kelas kurang dari 5 kelas akan menghasilkan peta yang kurang mencerminkan persebaran data asli, karena banyak data yang tergeneralisasi. Dibawah ini adalah rumus dalam penentuan jumlah kelas, yaitu:

$\mathrm{K}=1+3,3 \log n$

Keterangan:

$$
\begin{aligned}
& \mathrm{K}=\text { jumlah kelas yang dicari } \\
& \mathrm{n}=\text { jumlah data }
\end{aligned}
$$

\section{Penentuan interval kelas}

Penentuan interval kelas ditentukan dengan menggunakan rumus Kingma, yaitu:

$\mathrm{Ki}=\frac{\mathrm{Xt}-\mathrm{Xr}}{\mathrm{k}}$

Keterangan:

$$
\begin{aligned}
& \mathrm{Ki}=\text { kelas interval } \\
& \mathrm{Xt}=\text { data tertinggi (tahun tanam 1935) } \\
& \mathrm{Xr}=\text { data terendah (tahun tanam 2017) } \\
& \mathrm{k}=\text { jumlah kelas yang diinginkan }
\end{aligned}
$$

Pengambilan contoh tanah pada setiap SPL dilakukan pada 3 titik sebagai ulangannya. Setiap titik dilakukan pengambilan contoh tanah pada kedalaman $0-20 \mathrm{~cm}, 20-40 \mathrm{~cm}$ dan $40-60$ $\mathrm{cm}$. Hal ini karena sekitar $80-90 \%$, akar penyerap berada kedalaman $0-90 \mathrm{~cm}$ dari pangkal batang kopi. Namun, konsentrasi akar -

\begin{tabular}{|c|c|c|}
\hline Parameter & Satuan & Metode \\
\hline $\begin{array}{c}\text { KHJ } \\
\text { (konduktivitas } \\
\text { hidrolik jenuh) }\end{array}$ & $\mathrm{cm} \mathrm{jam}^{-1}$ & Constant head \\
\hline BI (berat isi) & $\mathrm{g} \mathrm{cm}^{-3}$ & Gravimetri \\
\hline BJ (berat jenis) & $\mathrm{g} \mathrm{cm}^{-3}$ & Piknometer \\
\hline Tekstur tanah & $\%$ & Hidrometer \\
\hline Porositas & $\%$ & $\begin{array}{c}1-(\mathrm{BI} / \mathrm{BJ} \\
\times 100 \%)\end{array}$ \\
\hline $\begin{array}{c}\text { Kemantapan } \\
\text { agregat }\end{array}$ & $\mathrm{Mm}$ & $\begin{array}{c}\text { Ayakan } \\
\text { basah }\end{array}$ \\
\hline
\end{tabular}
akar kopi pada kedalaman tanah $0-60 \mathrm{~cm}$ (Ferreira et al., 2019). Hasil kegiatan lapangan dianalisis dengan analisis laboratorium untuk sifat fisika tanah yang disajikan pada Tabel 1 .

Tabel 1. Parameter pengamatan.

Analisis data stastistik dilakukan untuk mengetahui pengaruh antar umur tanaman kopi 


\section{Jurnal Tanah dan Sumberdaya Lahan Vol 8 No 2: 493-504, 2021 \\ e-ISSN:2549-9793, doi: 10.21776/ub.jts1.2021.008.2.20}

terhadap nilai permeabilitas tanah dengan uji-t tidak berpasangan, dan untuk mengtahui hubungan antara hasil karakteristik sifat fisika tanah dengan permeabilitas menggunakan analisis korelasi dan regresi.

\section{Hasil dan Pembahasan}

\section{Kondisi umum wilayah}

Penelitian dilakukan di PT. Perkebunan Nusantara XII Kebun Bangelan yang terletak di Desa Bangelan, Kecamatan Wonosari, Kabupaten Malang. Lokasi penelitian berbatasan dengan Desa Sumber Tempur pada bagian utara, bagian timur berbatasan dengan Desa Sumbertempur, bagian selatan berbatasan dengan Desa Peniwen dan Kromengan serta bagian barat berbatasan dengan Desa Jambuwer. Luas lahan lokasi penelitian yaitu 466,92 ha. Komoditas yang terdapat di lokasi pengamatan yaitu kopi robusta sebagai komoditas utama. Selain kopi robusta, juga terdapat tanaman lainnya yaitu lamtoro sebagai tanaman penaung. Tanaman kopi robusta yang ditanam pada lokasi pengamatan merupakan tanaman yang ditanam pada tahun $1935-2017$. Ketinggian tempat lokasi penelitian berada pada $450-680 \mathrm{~m}$ di atas permukaan laut (mdpl), dengan topografi yang datar bergelombang dengan kemiringan lahan berkisar antara 8 $40 \%$. Jenis tanah di lokasi penelitian sebagian besar adalah Inceptisol (Widianto et al., 2017). Lokasi penelitian terdapat 5 SPL umur kebun kopi. Di setiap SPL memiliki karakteristik kebun kopi yang berbeda - beda seperti pada Tabel 2.

Tabel 2. Karakteristik SPL kebun kopi.

\begin{tabular}{|c|c|c|c|c|c|c|}
\hline \multirow[t]{2}{*}{ SPL } & \multicolumn{2}{|c|}{ Umur tanaman (tahun) } & \multicolumn{2}{|c|}{$\begin{array}{c}\text { Tanaman penaung } \\
\text { (pohon) }\end{array}$} & \multicolumn{2}{|c|}{ Penutup tanah } \\
\hline & Kelas & Rata - rata & Jenis & jumlah & Jenis & Kerapatan \\
\hline 1. & $84-67$ & 78 & Lamtoro & 21229 & Rumput & Tidak ada \\
\hline 2. & $66-50$ & 56 & Lamtoro & 42084 & Rumput & Tidak ada \\
\hline 3. & $49-33$ & 45 & Lamtoro & 10606 & Rumput & Rapat \\
\hline 4. & $32-16$ & 30 & Lamtoro & 9494 & Rumput & Rapat \\
\hline 5. & $15-1$ & 7 & Lamtoro & 33070 & Rumput & Tidak rapat \\
\hline
\end{tabular}

\section{Kemantapan agregat}

Nilai kemantapan agregat pada lokasi penelitian berkisar antara 4,25 - 5,14 mm (Tabel 3). Kelima SPL menunjukkan pada kedalaman 0 $60 \mathrm{~cm}$, nilai kemantapan agregat yang diperoleh tergolong dalam satu kelas yang sama yaitu sangat stabil sekali. Jenis tanah lokasi penelitian yaitu Inceptisol, dimana memiliki kandungan liat $\geq 40 \%$ (Arabia et al., 2018). Oleh karena itu, adanya kandungan liat yang tinggi dapat menyebabkan kemantapan agregat tanah tinggi (Pujawan et al., 2016).

\section{Berat isi, berat jenis dan porositas}

Berat isi tanah pada lokasi penelitian secara keseluruhan tergolong dalam kelas tinggi. Nilai berat isi tanah sebagian besar telah melampaui nilai kritis untuk tanah pertanian yaitu $1,2 \mathrm{~g} \mathrm{~cm}$ 3. Hal ini menunjukkan bahwa tanah pada lokasi penelitian terdapat indikasi pemadatan tanah. Saputra et al. (2018) menyatakan bahwa nilai berat isi tanah yang melampaui nilai kritis tanah pertanian sebesar $1,2 \mathrm{~g} \mathrm{~cm}^{-3}$ artinya tanah mengalami proses pemadatan. Nita et al. (2014) juga mengungkapkan bahwa tinggi rendahnya berat isi tanah ditentukan oleh banyaknya pori dan padatan tanah. Selain itu, pemberian bahan organik, besarnya tingkat agregasi, penembusan akar, pemadatan dan pengelolaan tanaman serta tanah merupakan hal yang dapat mempengaruhi berat isi tanah. Sementara itu, berat jenis tanah diseluruh SPL sebagian besar bernilai $>2 \mathrm{~g} \mathrm{~cm}^{-3}$ (Tabel 3). Khodijah (2019) menyatakan bahwa nilai berat jenis tanah menunjukkan nilai kerapatan partikel secara keseluruhan. Berat jenis tanah penting karena untuk mengetahui porositas dalam tanah. Nilai porositas yang dianalisis pada penelitian ini merupakan hasil perhitungan matematika menggunakan parameter berat isi dan berat jenis tanah. Nilai porositas pada lokasi penelitian berkisar antara $31,21-46,30 \%$ dan tergolong kelas sedang. Hal 


\section{Jurnal Tanah dan Sumberdaya Lahan Vol 8 No 2: 493-504, 2021 \\ e-ISSN:2549-9793, doi: 10.21776/ub.jts1.2021.008.2.20}

ini terjadi karena nilai berat isi yang diperoleh mengindikasikan adanya tanah yang mengalami pemadatan. Haryati (2014) menyatakan bahwa tanah yang mempunyai porositas total yang tinggi cenderung akan mempunyai berat isi yang rendah, karena berat isi yang rendah mengindikasikan tanah bersifat porous.

\section{Tekstur (pasit, debu dan liat)}

Tekstur tanah adalah perbandingan relatif antara fraksi pasir, debu dan liat. Tanah pada lokasi penelitian mempunyai tekstur tanah yang bervariasi yaitu liat, liat berdebu dan lempung liat berdebu. Sebagian besar tekstur tanah di seluruh SPL tergolong dalam kelas lempung liat berdebu dengan rata-rata pasir 15,68\%, debu $44,48 \%$ dan liat 39,85\%. Tekstur lempung liat berdebu ini tergolong dalam kategori agak halus. Djaenudin et al. (2011) menyatakan bahwa kelas tekstur agak halus terdiri dari tekstur lempung berliat, lempung liat berpasir, lempung liat dan berdebu. Tekstur tanah yang baik bagi tanaman kopi robusta yaitu kelas tekstur halus, agak halus dan sedang karena tergolong dalam kelas S1.

Tabel 3. Karakteristik sifat fisik tanah.

\begin{tabular}{|c|c|c|c|c|c|c|c|c|}
\hline \multirow[t]{2}{*}{ SPL } & \multirow{2}{*}{$\begin{array}{l}\mathrm{Kd} \\
(\mathrm{cm})\end{array}$} & \multirow{2}{*}{$\begin{array}{c}\text { Kemantapan } \\
\text { Agregat }(\mathrm{mm})\end{array}$} & \multirow{2}{*}{$\begin{array}{c}\mathrm{BI} \\
\left(\mathrm{g} \mathrm{cm}^{-3}\right)\end{array}$} & \multirow{2}{*}{$\begin{array}{c}\text { BJ } \\
\left(\mathrm{g} \mathrm{cm}^{-3}\right)\end{array}$} & \multirow{2}{*}{$\begin{array}{c}\text { Porositas } \\
\text { (\%) }\end{array}$} & \multicolumn{3}{|c|}{ Tekstur } \\
\hline & & & & & & $\begin{array}{c}\% \% \\
\text { Pasir }\end{array}$ & $\begin{array}{c}\% \\
\text { Debu }\end{array}$ & $\begin{array}{c}\% \\
\text { Liat }\end{array}$ \\
\hline \multirow[t]{3}{*}{1} & $0-20$ & 5,02 & 1,32 & 2,16 & 38,83 & 13,52 & 43,93 & 42,55 \\
\hline & $20-40$ & 4,62 & 1,21 & 2,21 & 45,32 & 12,55 & 47,68 & 39,76 \\
\hline & $40-60$ & 4,76 & 1,11 & 2,07 & 46,30 & 16,13 & 44,49 & 39,38 \\
\hline \multirow[t]{3}{*}{2} & $0-20$ & 5,14 & 1,26 & 2,07 & 39,14 & 17,47 & 43,59 & 38,93 \\
\hline & $20-40$ & 4,78 & 1,23 & 2,20 & 44,24 & 16,49 & 45,73 & 37,77 \\
\hline & $40-60$ & 4,25 & 1,25 & 2,17 & 42,14 & 15,05 & 49,35 & 35,60 \\
\hline \multirow[t]{3}{*}{3} & $0-20$ & 4,81 & 1,13 & 2,00 & 42,89 & 14,94 & 45,81 & 39,25 \\
\hline & $20-40$ & 4,86 & 1,20 & 2,00 & 39,74 & 14,38 & 42,77 & 42,85 \\
\hline & $40-60$ & 4,51 & 1,16 & 1,90 & 39,27 & 14,02 & 42,95 & 43,04 \\
\hline \multirow[t]{3}{*}{4} & $0-20$ & 5,11 & 1,43 & 2,09 & 31,21 & 17,72 & 45,73 & 36,55 \\
\hline & $20-40$ & 4,79 & 1,33 & 1,99 & 32,98 & 17,26 & 43,41 & 39,33 \\
\hline & $40-60$ & 5,06 & 1,31 & 2,11 & 37,57 & 15,15 & 44,00 & 40,85 \\
\hline \multirow[t]{3}{*}{5} & $0-20$ & 5,02 & 1,37 & 2,04 & 32,73 & 11,19 & 38,66 & 50,15 \\
\hline & $20-40$ & 4,99 & 1,14 & 2,00 & 42,73 & 18,37 & 42,80 & 38,83 \\
\hline & $40-60$ & 4,80 & 1,25 & 2,01 & 37,78 & 20,92 & 46,22 & 32,86 \\
\hline
\end{tabular}

\section{Permeabilitas tanah}

Permeabilitas tanah dari seluruh SPL di lokasi penelitian pada kedalaman $0-60 \mathrm{~cm}$ memiliki nilai yang beragam namun seluruhnya tergolong dalam kelas permeabilitas sedang dan agak cepat (Gambar 1). Nilai permeabilitas yang beragam ini karena adanya perbedaan karakteristik sifat fisika tanah dan umur kebun kopi. SPL 1 dan 2 merupakan kebun kopi yang tergolong tua. Rerata masing - masing umur tanaman kopi pada lokasi penelitian yaitu 78 tahun dan 56 tahun. Di SPL 2, jumlah tanaman penaung memiliki jumlah yang paling banyak. Sehingga memungkinkan adanya sistem perakaran yang jauh lebih berkembang. Hasil analisis laboratorium, nilai berat isi di setiap kedalaman semakin menurun dan porositas tanah semakin meningkat (Tabel 3). Menurut beberapa hasil penelitian menyatakan bahwa pertumbuhan dan berkembangan sistem perakaran tanaman di kebun kopi dapat mempengaruhi karakteristik tanah, termasuk makroporositas tanah, dan berdampak pada peningkatan permeabilitas tanah (Scholl et al., 2014; Vergani dan Graf, 2016; Jotisankasa dan Sirirattanachat, 2017; Shao et al., 2017; Leung et al., 2018). Beberapa karakteristik tanah yang mempengaruhi permeabilitas tanah adalah berat isi, porositas, tekstur tanah, distribusi ukuran pori dan kemantapan agregat (Haryati, 2014; Zhang et al., 2019). SPL 3 terdapat tanaman kopi yang mempunyai umur rata - rata 45 tahun, lamtoro dan terdapat rerumputan yang rapat. Adanya rerumputan yang terdapat di permukaan tanah tersebut membuat kondisi fisik tanah berubah. 
Jurnal Tanah dan Sumberdaya Lahan Vol 8 No 2: 493-504, 2021

e-ISSN:2549-9793, doi: 10.21776/ub.jts1.2021.008.2.20
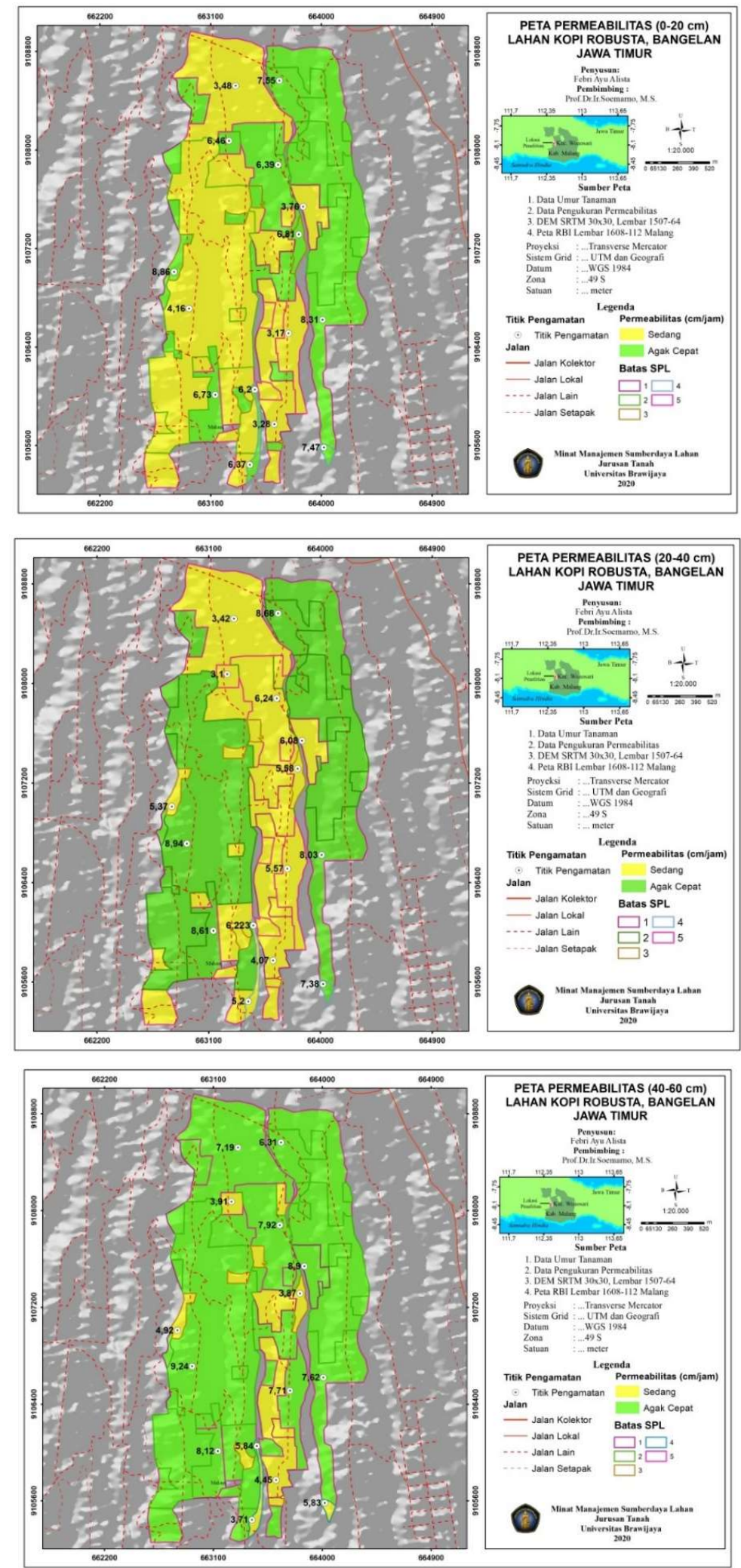

Gambar 1. Peta sebaran permeabilitas setiap kedalaman. 


\section{Jurnal Tanah dan Sumberdaya Lahan Vol 8 No 2: 493-504, 2021 e-ISSN:2549-9793, doi: 10.21776/ub.jts1.2021.008.2.20}

Umer (2018) menyatakan bahwa adanya rerumputan di permukaan tanah menyebabkan nilai berat isi menurun, sehingga porositas dalam tanah meningkat (Tabel 3). Kondisi tersebut menyebabkan nilai permeabilitas lebih tinggi pada lapisan atas. Tanah padat menunjukkan berat isi tinggi dan porositas menurun sehingga mengganggu dalam kecepatan tanah dalam meloloskan air serta perkembangan perakaran tanaman (Lal, 2017).

SPL 4 terdapat tanaman kopi yang mempunyai umur rata - rata 30 tahun, lamtoro sebagai tanaman penaung dan terdapat rerumputan yang rapat. Nilai kemantapan agregat tanah pada SPL 4 menunjukkan penurunan di setiap kedalaman tanah. Nilai kemantapan agregat tanah pada masing masing kedalaman yaitu 5,11 $\mathrm{mm}, 4,79 \mathrm{~mm}$ dan $5,06 \mathrm{~mm}$ (Tabel 3). Menurut Listyarini et al. (2018), semakin kecil nilai kemantapan agregat tanah, maka nilai permeabilitas akan rendah. Persentase kandungan liat juga semakin meningkat disetiap kedalamannya. Kandungan liat pada masing - masing kedalaman pada SPL 4 yaitu 36,55\%, 39,33\% dan 40,85\% (Tabel 3). Menurut Masria et al. (2018), tanah dengan partikel liat akan mempunyai banyak pori mikro sehingga permeabilitas lambat.

SPL 5 terdapat tanaman kopi yang mempunyai umur rata - rata 7 tahun dan lamtoro sebagai tanaman penaung. Menurut Prihadi (2009), adanya pohon penaung ini juga memberikan pengaruh secara tidak langsung terdahap sifat fisik tanah karena adanya tanaman penaung dapat menyumbangkan seresah di permukaan tanah untuk input bahan organik tanah. Bahan organik mempunyai peran dalam stabilitas agregat. Data pada Tabel 3 menunjukkan bahwa terdapat penurunan kandungan liat dan peningkatan porositas tanah disetiap kedalamannya. Partikel liat memiliki ruang pori yang kecil sehingga menyebabkan permeabilitas tanah lambat. Menurut Saputra $e t$ al. (2018), partikel liat merupakan partikel tanah yang dengan ukuran terkecil sehingga memiliki porositas total yang tinggi namun didominasi oleh pori mikro sehingga laju infiltrasi rendah dan begitu pula sebaiknya.

\section{Pengatuh antar umur tanaman kopi terhadap nilai permeabilitas tanah}

Permeabilitas pada SPL 2 dan 3 pada kedalaman $20-40 \mathrm{~cm}$ dan $40-60 \mathrm{~cm}$ terdapat perbedaan yang signifikan. Rata - rata nilai permeabilitas kedalaman $20-40 \mathrm{~cm}$ pada SPL 2 sebesar 7,95 $\mathrm{cm} \mathrm{jam}^{-1}$ (agak cepat) sedangkan pada SPL 3 sebesar 4,68 $\mathrm{cm} \mathrm{jam}^{-1}$ (sedang). Kemudian rata - rata nilai permeabilitas kedalaman $40-60 \mathrm{~cm}$ pada SPL 2 sebesar 7,82 $\mathrm{cm} \mathrm{jam}^{-1}$ (agak cepat) sedangkan pada SPL 3 sebesar 4,23 $\mathrm{cm} \mathrm{jam}^{-1}$ (sedang). Berdasarkan nilai permeabilitas yang diperoleh, perbedaan tersebut disebabkan oleh umur kebun kopi pada SPL 2 lebih tua daripada SPL 3 sehingga akar tanaman lebih berkembang. Berkembangnya akar tanaman akan menyebabkan peningkatan drainase dalam tanah sehingga dapat meningkatkan nilai permeabilitas. Vergani dan Graf (2015) menyatakan bahwa semakin bertambah umur tanaman akan diikuti dengan perkembangan sistem perakaran, sehingga akar tanaman yang semakin berkembang akan meningkatkan nilai permeabilitas tanah.

Permeabilitas pada SPL 3 dan 5 menunjukkan adanya perbedaan yang signifikan pada kedalaman $40-60 \mathrm{~cm}$. Rata - rata nilai permeabilitas kedalaman $40-60 \mathrm{~cm}$ pada SPL 3 sebesar 4,23 $\mathrm{cm} \mathrm{jam}^{-1}$ (sedang) sedangkan pada SPL 5 sebesar 7,51 cm jam ${ }^{-1}$ (agak cepat). SPL 5 merupakan lahan kebun kopi yang memiliki usia yang paling muda. Dalam proses budidaya tanaman kopi saat melakukan penanaman dilakukan pencampuran antara tanah galian dengan pupuk kandang sebesar $20 \mathrm{~kg}$ setiap lubang tanam. Hal tersebut memungkinkan adanya kandungan bahan organik dalam tanah tinggi sehingga. Menurut Iori et al. (2014, tanaman kopi umur tanaman 7 tahun terdapat perbedaan yang nyata pada stabilitas agregat dibandingkan pada stabilitas agregat pada umur tanaman kopi 2 tahun. Adanya peningkatan stabilitas agregat ini dapat menyababkan peningkatan laju infiltrasi dalam tanah.

Permeabilitas pada SPL 4 dan 5 menunjukkan adanya perbedaan yang signifikan pada kedalaman $40-60 \mathrm{~cm}$. Rata - rata nilai permeabilitas kedalaman $40-60 \mathrm{~cm}$ pada SPL 4 sebesar $5,21 \mathrm{~cm} \mathrm{jam}^{-1}$ (sedang) sedangkan pada SPL 5 sebesar $7,51 \mathrm{~cm} \mathrm{jam}^{-1}$ (agak cepat). Perbedaan kelas permeabilitas ini terjadi karena adanya pengaruh umur terhadap karakteristik sifat fisik tanah sehingga dapat mempengaruhi nilai permeabilitas. Vegetasi utama pada SPL 5 memiliki umur tanaman rata - rata 7 tahun, sedangkan pada SPL 4 memiliki umur tanaman rata - rata 30 tahun. Hasil penelitian Iori et al. 
(2014) menunjukkan bahwa pada umur tanaman kopi 2, 7 dan 18 tahun nilai bahan organik, porositas berat isi dan stabilitas agregat menunjukkan adanya perbedaan yang nyata. Namun pada usia 33 tahun terdapat penurunan bahan organik, porositas, berat isi dan stabilitas agregat. Kondisi tersebut memberikan pengaruh terhadap kecepatan tanah dalam meloloskan air.

\section{Hubungan kemantapan agregat dengan permeabilitas tanah}

Uji korelasi dan regresi antara kemantapan agregat dan permeabilitas tanah memiliki hubungan yang erat dengan $r=0,4603$ (Gambar 2). Kemantapan agregat berpengaruh $14 \%$ terhadap permeabilitas tanah. Hal ini bertolak belakang dengan Listyarini et al. (2018) yang melaporkan bahwa kemantapan agregat berbanding lurus dengan konduktifitas hidraulik jenuh. Faktor yang mempengaruhi perbedaan tersebut karena adanya kandungan liat yang tinggi sehingga menyebabkan tanah semakin mantap nilai permeabilitas menurun. Pujawan et al. (2016) juga menambahkan bahwa tanah yang mengandung liat tinggi menyebabkan tanah memiliki kemantapan agregat yang tinggi.

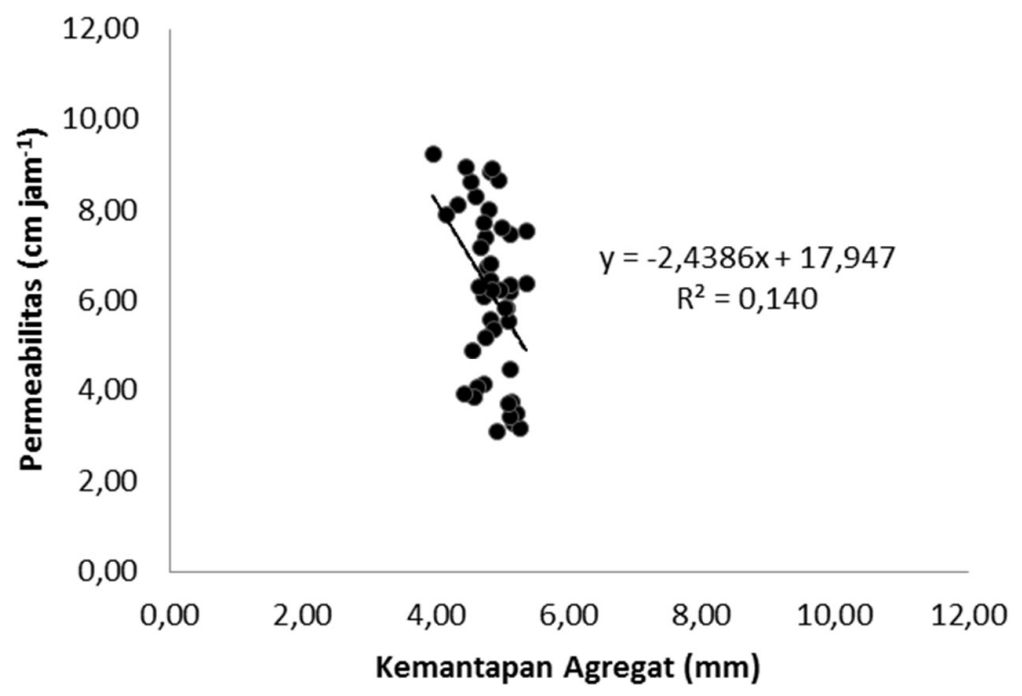

Gambar 2. Hubungan kemantapan agregat dengan permeabilitas.

\section{Hubungan berat isi dengan permeabilitas tanah}

Berat isi dan permeabilitas tanah memiliki hubungan yang erat dengan $\mathrm{r}=0,3271$. Gambar 3 menunjukkan hubungan antara berat isi dan permeabilitas tanah yaitu berbanding terbalik dan besaran pengaruhnya yaitu 2,5\%. Berat isi tanah berkaitan dengan porositas tanah, semakin tinggi berat isi tanah akan semakin rendah porositasnya sehingga nilai permeabilitas rendah. Menurut Widianto et al. (2017), hubungan antara berat isi dengan porositas tanah menunjukkan kecenderungan negatif yaitu semakin tinggi berat isi maka akan semakin rendah porositas dan begitu pula sebaliknya. Nurwidyanto (2005) juga mengungkapkan bahwa terdapat korelasi atau hubungan yang nyata dan bersifat positif antara porositas dengan permeabilitas tanah. Sehingga hubungan berat isi dan permeabilitas tanah memiliki hubungan yang kuat dimana berat isi mempengaruhi permeabilitas sebesar 2,5\%.

\section{Hubungan porositas dengan permeabilitas tanah}

Porositas dan permeabilitas mempunyai hubungan yang erat dengan $r=0,5835$. Gambar 4 menunjukkan bahwa hubungan antara porositas dengan permeabilitas yaitu berbanding lurus dan besaran pengaruhnya yaitu 17,6\%. Porositas merupakan volume ruang pori total dalam tanah yang kosong dan tidak ditempati oleh bahan padat tanah. Adanya ruang kosong tersebut dapat meningkatkan permeabilitas tanah. Menurut Listyarini et al. (2018), 
konduktifitas hidraulik jenuh tanah dan porositas memiliki hubungan yang berbanding lurus karena ruang pori tanah yang kosong dan tidak terisi oleh bahan mineral ataupun yang lainnya akan memperbesar kemampuan tanah dalam mengalirkan air (permeabilitas). Wahyuni dan Tri (2016) juga mengungkapkan bahwa porositas tanah yang tinggi akan mengakibatkan tanah akan mudah untuk meneruskan air, sehingga pergerakan air semakin cepat.

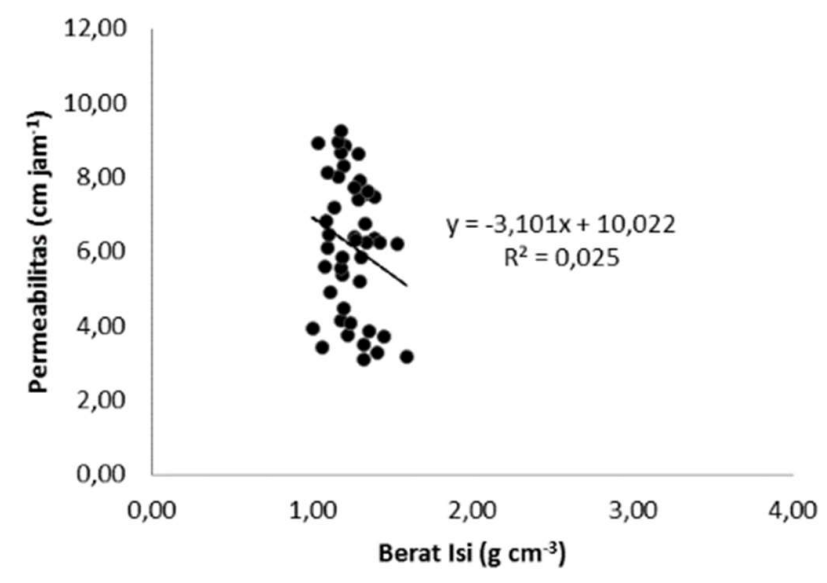

Gambar 3. Hubungan berat isi dengan permeabilitas.

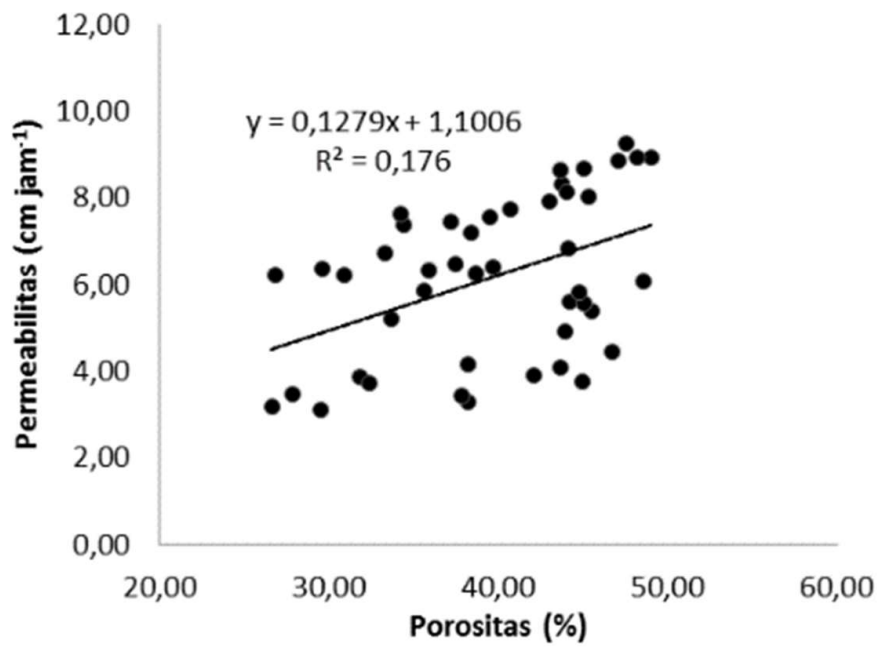

Gambar 4. Hubungan porositas dengan permeabilitas.

Hubungan tekstur tanah (pasir, debu, dan liat) dengan permeabilitas tanah

Partikel pasir, debu dan liat dengan permeabilitas tanah memiliki hubungan yang erat. Berdasarkan Gambar 5 diketahui bahwa hubungan antara pasir dan debu terhadap permeabilitas tanah memiliki hubungan berbanding lurus. Pada partikel liat terhadap permeabilitas tanah memiliki hubungan berbanding terbalik. Hal ini karena tanah yang mengandung banyak partikel pasir mempunyai pori makro, debu mempunyai pori meso dan liat mempunyai pori mikro. Perbedaan ukuran pori tersebut dapat mempengaruhi kecepatan tanah dalam meloloskan air. Menurut Wahyuni dan Tri (2016), partikel pasir memiliki pori tanah makro, dimana mengakibatkan tanah akan mudah dalam meloloskan air sehingga pergerakan air semakin cepat. 
Jurnal Tanah dan Sumberdaya Lahan Vol 8 No 2: 493-504, 2021

e-ISSN:2549-9793, doi: 10.21776/ub.jts1.2021.008.2.20
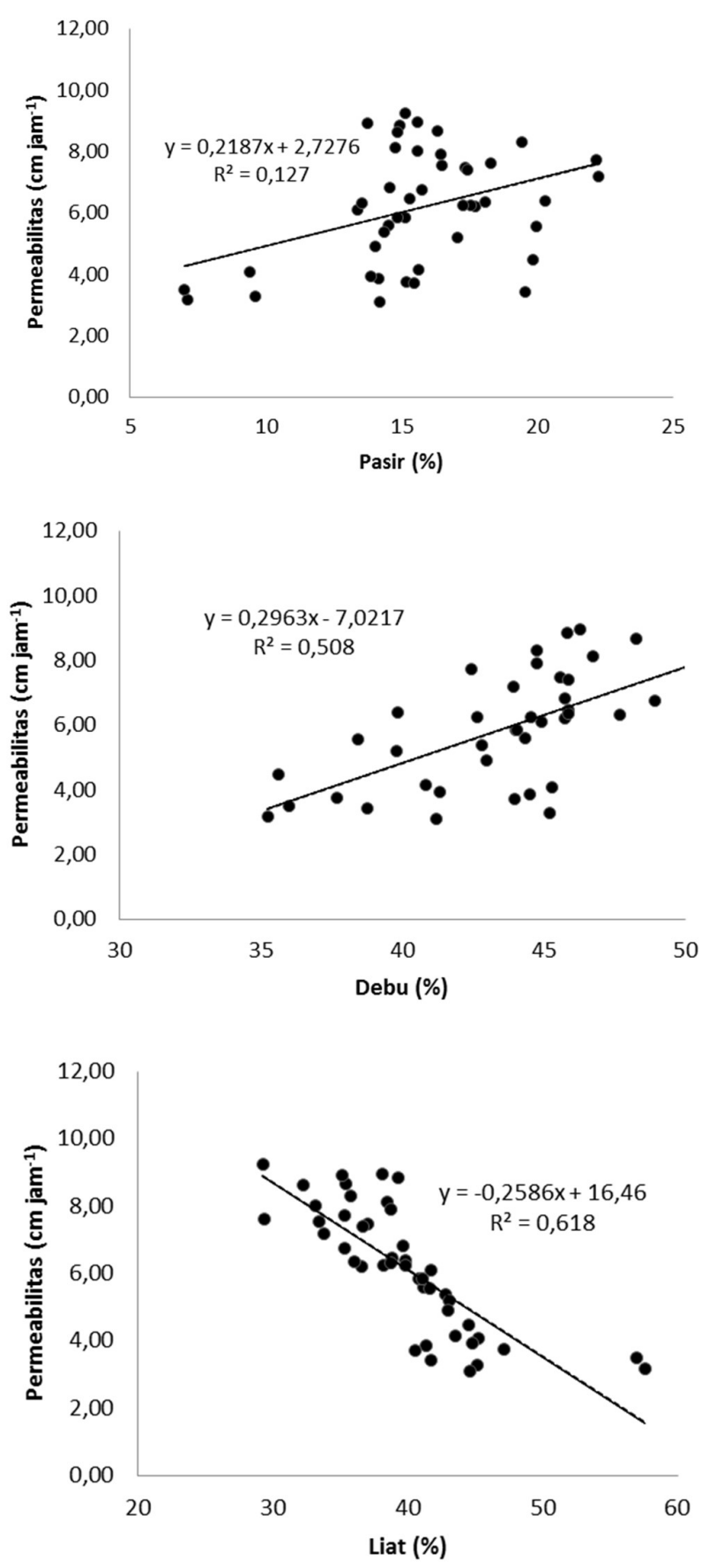

Gambar 5. Hubungan kandungan partikel primer dengan permeabilitas tanah.

Masria et al. (2018) menyatakan bahwa tanah yang didominasi partikel pasir akan mempunyai pori makro, debu mempunyai pori meso dan liat mempunyai pori mikro. Dariah et al. (2006) menyatakan bahwa pori tanah sangat menentukan tinggi rendahnya permeabilitas dimana permeabilitas akan mendekati nol apabila pori tanah sangat kecil, seperti pada tanah liat. Hasil uji korelasi antara partikel pasir, debu dan liat dengan permeabilitas diperoleh nilai $\mathrm{r}$ masing - masing 0,$3888 ; 0,7147$; dan 0,7668. Masing - masing partikel tanah tersebut 


\section{Jurnal Tanah dan Sumberdaya Lahan Vol 8 No 2: 493-504, 2021}

e-ISSN:2549-9793, doi: 10.21776/ub.jts1.2021.008.2.20

mempunyai pengaruh sebesar $12,7 \%, 50,8 \%$ dan $61,8 \%$.

\section{Hubungan permeabilitas terhadap produksi}

Hubungan permeabilitas dan produksi menunjukkan bahwa terdapat hubungan yang erat dengan nilai $\mathrm{r}=0,4878$ dan berbanding lurus. Berdasarkan Gambar 6, permeabilitas dengan produksi memiliki hubungan berbanding lurus dan besaran pengaruhnya yaitu $16,9 \%$. Permeabilitas yang tinggi diikuti dengan ruang pori yang tinggi, akar tanaman semakin mudah menembus tanah dalam menyerap hara. Semakin mudah akar tanaman menembus tanah mengindikasikan adanya drainase yang baik. Hal tersebut dapat mempengaruhi kondisi tanah pertanian yang lain seperti aerasi tanah, kelembapan tanah dan hasil tanaman. Sehingga menyebabkan pertumbuhan dan perkembangan tanaman semakin baik dan memberikan hasil yang lebih tinggi. Menurut Sandrawati (2016), terdapat hubungan yang positif antara bobot isi, porositas dan permeabilitas tanah terhadap produksi tanaman. Akar tanaman akan semakin mudah menembus tanah sehingga menyebabkan pertumbuhan dan perkembangan tanaman cepat dan memberikan hasil yang lebih tinggi. Vergani dan Graf (2015) juga mengungkapkan bahwa adanya aktivitas sistem perakaran akan memperbaiki drainase tanah. Drainase dapat mempengaruhi kondisi tanah pertanian seperti aerasi tanah, kelembapan tanah, transportasi dan keefektifan nutrien dan pestisida, suhu tanah, hama penyakit, erosi tanah, kesuburan tanah dan hasil tanaman (Effendy, 2011).

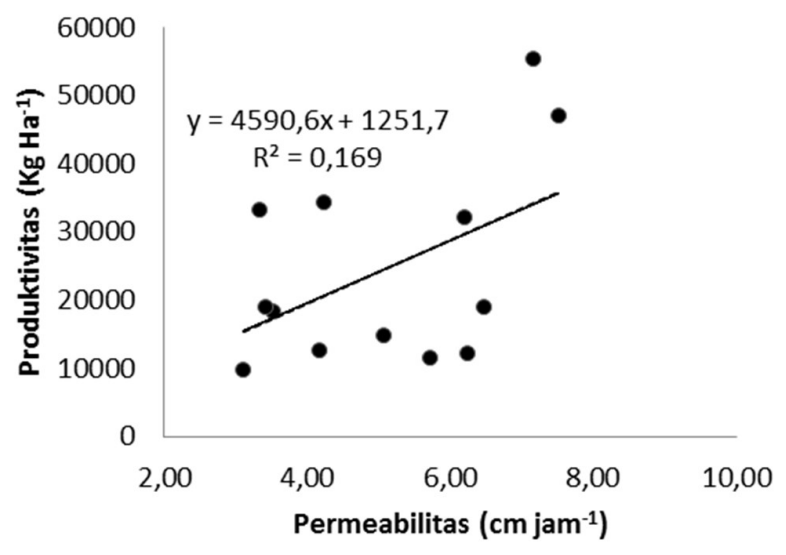

Gambar 6. Hubungan permeabilitas terhadap produksi.

\section{Kesimpulan}

Permeabilitas tanah pada lokasi penelitian memiliki kelas permeabilitas sedang dan agak cepat. Nilai permeabilitas tanah yang tertinggi terdapat pada SPL 2 pada rata - rata umur kebun kopi robusta 56 tahun. Kemantapan agregat, berat isi, porositas dan tekstur tanah berpengaruh nyata terhadap permeabilitas tanah. Permeabilitas tanah berpengaruh nyata terhadap produktivitas tanaman kopi robusta dengan arah korelasi yang positif.

\section{Ucapan Terima Kasih}

Penulis menyampaikan ucapamna terima kasih kepada dtaf Afdeling Besaran, PTPN XII Kebun
Bangelan atas bantuannya dalam pengambilan sampel tanah untuk penelitian ini.

\section{Daftar Pustaka}

Arabia, T., Manfarizah. Syakur, S. dan Irawan, B. 2018. Karakteristik tanah Inceptisol yang disawahkan di Kecamatan Indrapuri Kabupaten Aceh Besar. Jurnal Floratek 13(1): 1 - 10.

Baroh, I., Hanani, N., Setiawan, B. and Koestiono, D. 2014. Indonesian coffee competitiveness in the international market: review from the demand side. International Journal of Agriculture Innovations and Research 3 (2): 605 - 609.

BPS (Badan Pusat Statistik). 2019. Luas dan Produksi Kopi Rakyat Menurut Kecamatan Di Kabupaten Malang Tahun 2016 - 2018. BPS: Malang.

Dariah, A., Yusrial dan Mazwar. 2006. Penetapan 


\section{Jurnal Tanah dan Sumberdaya Lahan Vol 8 No 2: 493-504, 2021 e-ISSN:2549-9793, doi: 10.21776/ub.jts1.2021.008.2.20}

Konduktivitas Hidrolik Tanah dalam Keadaan Jenuh: Metode Laboratorium. Bogor: Balai Besar Litbang Sumberdaya Lahan Pertanian.

Dinas Perkebunan Jawa Timur. 2017. Komoditas Unggulan: Kopi. Tersedia di: (http://www.disbun.jatimprov.go.id/komoditi_ kopi.php) [Diakses 1010 2019].

Djaenudin, D., Marwan, H., Subagjo, H. dan A. Hidayat. 2011. Petunjuk Teknis Evaluasi Lahan Untuk Komoditas Pertanian. Bogor: Balai Besar Litbang Sumberdaya Lahan Pertanian.

Effendy. 2011. Drainase untuk Meningkatkan Kesuburan Lahan Rawa. PILAR Jurnal Teknik Sipil 6 (2): $39-44$.

Ferreira, T., Shuler, J., Guimarães, R. and Farah, A. 2019. Chapter 1: Introduction to Coffee Plant and Genetics, in Coffee: Production, Quality and Chemistry. Page: $1-25$ [Online] Available at: (https://pubs.rsc.org/en/content/chapterhtml/ 2019/bk9781782620044-00001 ?isbn $=978^{-1}$ 78262-004-4\&sercode=bk) [Diakses 279 2020].

Hairiah, K., Suprayogo, D., Widianto., Berlian., Prayogo, C., Suhara, E., Mardiastunning, A., Widodo, R.H. dan Rahayu, S. 2004. Alih guna lahan hutan menjadi lahan agroforestri berbasis kopi: ketebalan seresah, populasi cacing tanah dan makroporositas tanah. Agrivita 26 (1): 68 80.

Haryati, U. 2014. Karakteristik fisik tanah kawasan budidaya sayuran dataran tinggi hubungannya dengan strategi pengelolaan lahan. Jurnal Sumberdaya Lahan 8(2): 125 - 138.

Iori, P., Junior, M.D.S.D., Ajayi, A.E., Guimaraes, P.T.G. and. Junior, A.A.A. 2014. Influence of field slope and coffee planatation age on the physical properties of a red-yellow Latosol. The Revista Brasileira de Ciência do Solo 38: 107 117.

Jotisankasa, A. and Sirirattanachat, T. 2017. Effects of grass roots on soil-water retention curve and permeability function. Canadian Geotechnical Journal. 54(11): 1612 - 1622.

Khodijah, S. dan Soemarno. 2019. Studi kemampuan tanah menyimpan air tersedia di sentra bawang putih Kecamatan Pujon, Kabupaten Malang. Jurnal Tanah dan Sumberdaya Lahan 6(2): 1405 $-1414$.

Lal, R. 2017. Bulk Density dalam Lal. Encyclopedia of Soil Science: Third Edition. Taylor dan Francis Group.

Leung, A.K., Boldrin, D., Liang, T., Wu, Z.Y., Kamchoom, V. and Bengough, A.G. 2018. Plant age effects on soil infiltration rate during early plant establishment. Géotechnique 68(7): 646652.

Listyarini, E. dan Isnawati, N. 2018. Hubungan antara kemantapan agregat dengan konduktifitas hidraulik jenuh tanah pada berbagai penggunaan lahan di Desa Tawangsari Kecamatan Pujon, Malang. Jurnal Tanah dan Sumberdaya Lahan 5(1): $785-791$.

Masria, C.L., Zubair, H. dan Rasyid, B. 2018. Karakteristik pori dan hubungannya dengan permeabilitas pada tanah Vertisol asal Jeneponto Sulawesi Selatan. Jurnal Unhas 1(1): 1 - 7.

Nita, I., Listyarini, E. dan Kusuma, Z. 2014. Kajian lengas tersedia pada toposekuen lereng utara G. Kawi Kabupaten Malang Jawa Timur. Jurnal Tanah dan Sumberdaya Lahan 1(2): 53-62.

Nurwidyanto, M., Irham, I., Noviyanti dan Widodo, S. 2005. Estimasi hubungan porositas dan permeabilitas pada batupasir (study kasus formasi Kerek, Ledok, Selorejo). Jurnal Berkala Fisika 8 (3): $87-90$.

Prihadi, T.S. 2009. Sifat Fisika Tanah pada Beberapa Naungan di Kebun Kopi Robusta. Jember: Universitas Jember.

Pujawan, M.A., Novpriansyah, H. dan Manik, K.E.S. 2016. kemantapan agregat tanah pada lahan produksi rendah dan tinggi di PT Great Giant Pineapple. Jurnal Agrotek Tropika 4 (1): 111 115

Sandrawati, A., Setiawan, A. dan Kesumah, G. 2016. Pengaruh kelas kemiringan lereng dan penggunaan lahan terhadap sifat fisik tanah di kawasan penyangga Waduk Cirata Kecamatan Cipeundeuy Kabupaten Bandung Barat. Soilrens 14(1): 6-10.

Saputra, D.D., Putrantyo, A.R. dan Kusuma, Z. 2018. Hubungan kandungan bahan organik tanah dengan berat isi, porositas dan laju infiltrasi pada perkebunan salak di Kecamatan Purwosari, Kabupaten Pasuruan. Jurnal Tanah dan Sumberdaya Lahan 5 (1): 647 - 654.

Scholl, P., Leitner, D., Kammerer, G., Loiskandl, W., Kaul, H.P. and Bodner, G. 2014. Root induced changes of effective 1D hydraulic properties in a soil column. Plant and Soil 381(1 - 2): 193 - 213.

Shao, W., Ni, J., Leung, A.K., Su, Y. and Ng, C.W.W. 2017. Analysis of plant root-induced preferential flow and pore-water pressure variation by a dualpermeability model. Canadian Geotechnical Journal 54(11): 1537-1552.

Simanjuntak, B.H. 2005. Studi alih fungsi lahan hutan menjadi lahan pertanian terhadap karakteristik fisik tanah (studi kasus DAS Kali Tundo, Malang). Agric 18 (1): 85 - 101.

Siregar, N., Sumono, A. dan Munir, A.P. 2013. Kajian permeabilitas beberapa jenis tanah di lahan percobaan Kwala Berkala USU melalui uji laboratorium dan lapangan. Jurnal Rekayasa Pangan dan Pertanian 1(4): 138 - 143.

Sturges, H.A. 1926. The choice of a class interval. Journal American Statistical Association 21: 65 66. 


\section{Jurnal Tanah dan Sumberdaya Lahan Vol 8 No 2: 493-504, 2021 \\ e-ISSN:2549-9793, doi: 10.21776/ub.jts1.2021.008.2.20}

Suprayogo, D., Widianto., Purnomosidi, P., Widodo, R.H., Rusiana, F., Aini, Z.Z., Khasanah, N. dan Kusuma, Z. 2004. Degradasi sifat fisika tanah sebagai akibat alih guna lahan hutan menjadi sistem kopi monokultur: kajian perubahan makroporositas tanah. Agrivita 26 (1): $60-68$.

Umer, S., Aticho, A. and Kiss, E. 2019. Effects of integrated use of grass strip and soil bund on soil properties, Southern Ethiopia. Journal of Degrades and Mining Lands Management 6(2): $1569-1578$.

Vergani C. and Graf, F. 2015. Soil Permeability, Aggregate Stability and Root Growth: A Pot Experiment from a Soil Bioengineering Perspective. Ecohydrol. Switzerland: WSL Institute for Snow and Avalanche Research SLF, Flüelastrasse 11.

Wahyuni, D. dan Handayani, T. 2016. Pengaruh sifat fisik tanah terhadap konduktivitas hidrolik jenuh pada lahan pertanian produktif di Desa Arang Limbung Kalimantan Barat. Jurnal Prisma Fisika 4 (1): $28-35$.

Wahyunto dan Dariah, A. 2014. Degradasi lahan di Indonesia: kondisi existing, karakteristik, dan penyeragaman definisi mendukung gerakan menuju satu peta. Jurnal Sumberdaya Lahan 8 (2): $81-93$.
Widianto., Suprayogo, D., Noveras, H., Widodo, R.H., Purnomosidhi, P. dan van Noordwijk, M. 2004. Alih guna lahan hutan menjadi lahan pertanian: apakah fungsi hidrologis hutan dapat digantikan sistem kopi monokultur?. Agrivita 26(1): $47-52$.

Widianto., Surya, J.A. dan Nuraini, Y. 2017. Kajian porositas tanah pada pemberian beberapa jenis bahan organik di perkebunan kopi robusta. Jurnal Tanah dan Sumberdaya Lahan 4 (1): 463 - 471.

Wulandari, I.S. 2010. Perbandingan ekspor kopi dua pemasok utama dunia indonesia dan brazil: sebuah analisis ekonomi data panel 2001 - 2006. UNISIA 33(73): 3 - 16 .

Zhang, Z., Lio, K.L., Zhou, H., Lin, H., Li, D. and Peng, X. 2019. Linking saturated hydraulic conductivity and air permeability to the characteristics of biopores derived from X-ray computed tomography. Journal of Hydrology 571: 1 - 10. 